\title{
The Effect of Decentralization, Task Uncertainty and Environment Uncertainty on the Managerial Performance: Management Accounting System Dimensions as Mediation Variables
}

\author{
Alfriadi Dwi Atmoko ${ }^{1 *}$, Dody Hapsoro ${ }^{1}$ \\ ${ }^{1}$ STIE YKPN , Daerah Istimewa Yogyakarta \\ Email: alfriadidwi@gmail.com
}

\begin{abstract}
This study aims to empirically examine the effect of decentralization, task uncertainty and environment uncertainty on managerial performance with Management Accounting System (MAS) dimensions that consist of broad scope, timeliness, aggregation and integration as mediating variables. This study was conducted on a variety of business sectors in Yogyakarta, Indonesia. The respondents selected for this study were low, middle and top level managers of companies in various business sectors. The research sample consisted of 125 managers. The hypothesis in this study was tested with a regression-path analysis with an analytical method of the Partial Least Square following the pattern of the Structural Equation Modeling with WarpPLS application 5.0. The results of this study show that decentralization, task uncertainty and environment uncertainty have positive effects on managerial performance mediated by four MAS dimensions that consist of broad scope, timeliness, aggregation and integration. However, task uncertainty has a negative effect on the dimension of broad scope. In other words, the broad scope dimension cannot mediate the effect of task uncertainty on managerialperformance.
\end{abstract}

Keywords: Contingency Theory, Decentralization, Task Uncertainty, Environment Uncertainty, Management Accounting System and Managerial Performance.

\section{Introduction}

The fast-moving world development or globalization today has made increasingly tight business competition in most of the cities in Indonesia, including Yogyakarta. Notwithstanding the fact that it is not an industrial city, business development in this city experienced a positive trend. Construction of hotels, apartments, tourism services, coffee shops, transportation services and culinary businesses are some of the results of business development in this city. In order to maintain their viability in business competition, companies must adopt the best businessstrategy.

In the words of Widarsono (2007), managerial performance is the degree of how well managers perform their duties as managers. A company's success in implementing business strategy 
depends on the managers' ability on decision making. Their role is very important in making the adopted business strategy run in accordance with company objectives. To make their companies sustainable, managers require necessary information to make the right decision. The information required by managers is in the form of financial and non-financial statements produced with the assistance of management accounting system (MAS), which is processed by the management accountants in a company. Management accountant should consider the contingency factors that may affect the design of MAS. The contingency approach used in management accounting is based on a premise that there is no appropriate accounting system that fits all organizations in different situations (Otley, 1980).

MAS is a formal system that is designed to provide information for managers (Bouwens and Abernethy, 2000). MAS can help managers in controlling activities and minimizing uncertainty and so it is expected to assist companies in achieving their objectives (Gordon and Miller 1976; Kaplan 1984; Anthony et al. 1998). The contingency factors to be matched with MAS are decentralization, task uncertainty, environment uncertainty and so forth.

Decentralization can be defined as the delegation of authority from top-level managers to lower-level managers. High decentralization has a positive effect for MAS dimensions because decentralized managers need more information produced by MAS dimensions for proper decision making. The results of research Gul and Chia (1994), Chia (1995) and Nazaruddin (1998) showed that MAS information characteristics depend on the organization contingency variable, namely decentralization.

Hinings et al. (1974) define task uncertainty as the lack of information about events in the future so that alternative actions and their resulting outcome become unpredictable. According to Robbin (1994, task variability is a problem in a task assignment, which means that there are unexpected events in the task assignment process. Environment uncertainty is an external condition experienced by all business sectors in the world. Information technology change is one of the causes of uncertainty. Environment uncertainty demands company managers to implement the right business strategy to remain viable in a sustainable manner. Environment uncertainty has been identified a variable that can affect managerial performance (Gul and Chia, 1994; Chong and Chong, 1997).

\section{Literature Review and Hypothesis Development}

\subsection{Literature Review}

\subsubsection{Contingency Theory}

The contingency approach used in management accounting is based on a premise that there is no appropriate accounting system that fits all organizations in a variety of situations (Otley, 1980). The special feature of a proper accounting system depends on the state of an organization. The contingency theory must identify the aspects of management accounting system dimensions that match with organization conditions (Otley, 1980).

According to Islam and $\mathrm{Hu}$ (2012), the contingency theory is an approach for studying the organization structure that depends on factors such as technology, culture and external environment that affect the design and functions ofthe organization. The underlying assumption 
of the contingency theory is that there is no one type of organizational structure which is applicable to all organizations (Islam and $\mathrm{Hu}, 2012$ ).

\subsubsection{Decentralization}

Decentralization is the delegation of authority from top-level managers to lower level managers. According to Dwirandra (2007), decentralization is the delegation of authority and responsibility to lower level managers. Waterhouse and Tiessen (1978) write that the higher degree of autonomy delegated to managers in terms of responsibility for activity planning and controlling requires more information for decision-making.

\subsubsection{Task Uncertainty}

Hirst (1981) divides task uncertainty into two, namely high task uncertainty and low task uncertainty. High task uncertainty can be interpreted as a condition of a task that cannot be understood by employees. High task uncertainty makes employees lack sufficient knowledge of their job and not know what to do, while low task uncertainty is a condition when employees can understand their duties properly. Task uncertainty is the difference between the amount of information needed for task execution and the amount of information available for manager. The amount of information needed by a manager for decision making is a matter of consideration when experiencing a situation of task uncertainty (Chong, 1996).

\subsubsection{Environment Uncertainty}

The environment uncertainty is an external condition experienced by all business sectors in the world. Information technology change is one of the causes of environment uncertainty. Environment uncertainty requires company managers to implement the right business strategy in order to remain viable in a sustainable manner. Environment uncertainty has been identified as a variable that can affect managerial performance (Gul and Chia, 1994; Chong and Chong, 1997).

\subsubsection{Management Accounting System(MAS)}

Atkinson et al. (1995) define MAS as a system that collects financial and operational data to be processed, stored and reported to users. MAS is a formal system that is designed to provide information for managers (Bouwens and Abernethy, 2000). Chenhall and Morris (1986) formulate four dimensions of MAS, i.e. broad scope, timeliness, aggregation and integration.

a. Broad scope. The broad scope dimension includes focus, quantification, and time horizon. Focus is information relating to the economics, technology and market information. Quantification is related to financial information (GNP and sales total) and non-financial information (demography, consumer, competitor and technology). Time horizon is associated with past information and predictive future probabilities (sales trend).

b. Timeliness. The timeliness dimension has two reporting criteria, namely the frequency of reporting and speed of reporting. The frequency of reporting is defined how often the information is provided to managers in the period, while the speed of reporting is defined as the interval between the need for information and the availability of the needed information.

c. Aggregation. The aggregation dimension has three criteria, namely information by function, the time period and the decision model. Information by function is the provision of information related to the result of a decision made by another unit. Information concerning 
the time period is the information used by managers to assess their own decisions from time to time. The decision model information is the information used to make decisions with analytical models (inventory model, profit analysis, cash flow analysis).

d. Integration. Integration dimension is the coordination between one unit and other units within the organization. Integrated information includes provision target aspects or activities calculated at the process of the interaction between sub-units and the organization.

\subsubsection{Management Performance}

Managerial performance is a measurement of how effective and efficient managers'performance in an organization is. Managerial performance is one factor that can improve organization effectiveness (Supomo and Indriantoro, 1998). Mahoneyet al. (1963) state manager performance is measured through work dimension evaluation. Work dimension referred to by Mahoney et al. (1963) includes eight sub-dimensions ofwork, namely: Planning, Investigation, Coordination, Evaluation, Supervision, Staffing, Negotiation and Representation.

\subsection{Hypothesis Development}

\subsection{The Effect of Decentralization on MAS Dimension}

Chenhall and Morris's research (1986) found that on two MAS dimensions: aggregation and integration, decentralization has positive impacts. Conversely, it does not affect the other two MAS dimensions: broad scope and timeliness. Chenhall and Morris's research (1986) proved that integrated information can reduce problems in coordinating organizational subunits. Their findings are supported by the study of Soobaroyen and Poorundersing (2008) who concluded that the level of decentralization is positively associated with the four dimensions of MAS. Based on the above explanation, the hypotheses of this study are formulated as follows:

$\mathrm{H}_{1 \mathrm{a}}$ : $\quad$ Decentralization positively affects the broad scope dimension of MAS.

$\mathrm{H}_{1 \mathrm{~b}}$ : Decentralization positively affects the timeliness dimension of MAS.

$\mathrm{H}_{1 \mathrm{c}}$ : Decentralization positively affects the aggregation dimension of MAS.

$\mathrm{H}_{1 \mathrm{~d}}$ : Decentralization positively affects the integration dimension of MAS.

\subsection{The Effect of Task Uncertainty on MASDimension}

Task uncertainty is the difference between the amount of information needed to carry out the task and the amount of obtained information for manager. Thus, managers need information generated by MAS to decide when their company faces high task uncertainty (Chong, 1996). Managers in facing high task uncertainty will have difficulty in identifying the task priority. Therefore, managers need information that is generated by MAS dimensions to facilitate the work. Thus, task uncertainty affects the four dimensions of MAS to generate the information required by managers in decision-making. Based on the above explanation, another set of hypotheses can be formulated as follows:

$\mathrm{H}_{2 \mathrm{a}}$ : Task uncertainty positively affects the broad scope dimension of MAS.

$\mathrm{H}_{2 \mathrm{~b}}$ : Task uncertainty positively affects the timeliness dimension of MAS.

$\mathrm{H}_{2 \mathrm{c}}$ : Task uncertainty positively affects the aggregation dimension ofMAS.

$\mathrm{H}_{2 \mathrm{~d}}$ : Task uncertainty positively affects the integration dimension of MAS. 
When environment uncertainty increases, managers need information generated by MAS dimensions so that the decisions they make can be effective (Gordon and Narayanan, 1984). The research of Gul (1991), Gul and Chia (1994) and Mia and Chenhall (1994) found that environment uncertainty affects the MAS dimensions, which in turn can improve managerial performance. From the above explanation, it can be concluded that increasing environment uncertainty will increase the need for information generated by MAS dimensions for the information produced to be relevant to the actual circumstances. Based onthe above explanation, the third set of hypotheses can be formulated as follows:

$\mathrm{H}_{3 \mathrm{a}}$ : $\quad$ Environment uncertainty positively affects the broad scope dimension o fMAS.

$\mathrm{H}_{3 \mathrm{~b}}$ : Environment uncertainty positively affects the timeliness dimension of MAS.

$\mathrm{H}_{3 \mathrm{c}}$ : Environment uncertainty positively affects the aggregation dimension of MAS.

$\mathrm{H}_{3 \mathrm{~d}}$ : Environment uncertainty positively affects the integration dimension of MAS.

\subsubsection{The Effect of MAS on Performance Management}

Chia (1995) showed that the four dimensions of MAS, which consist of broad scope, timeliness, aggregation and integration, positively affect managerial performance, albeit in high decentralization conditions only. Nazaruddin (1998) found that MAS dimensions have a positive effect on managerial performance. The same is also shown in the results of research conducted by Soobaroyen and Poorundersing (2008). Based on the above explanation, hypotheses can be formulated as follows:

$\mathrm{H}_{4 \mathrm{a}}$ : The broad scope dimension positively affects managerial performance of MAS.

$\mathrm{H}_{4 \mathrm{~b}}$ : The timeliness dimension positively affects managerial performance of MAS.

$\mathrm{H}_{4 \mathrm{c}}$ : The aggregation dimension positively affects managerial performance of MAS.

$\mathrm{H}_{4 \mathrm{~d}}$ : The integration dimension positively affects managerial performance of MAS.

2.2.5 The Effect of Decentralization, Task Uncertainty and Environmental Uncertaintyon Managerial Performance with MAS Dimensions as MediationVariables

Otley (1980) wrote that a contingency approach used in accounting management is based on a premise that there is no accounting system appropriate for all organizations in all varieties of situations. The special feature of proper accounting system will depend on the circumstances of each organization. Contingency theory should identify the aspects of MAS dimensions that match with the conditions of the organization (Otley, 1980). Therefore, decentralization, task uncertainty and environment uncertainty as contextual variables should be matched to the MAS dimensions to facilitate managers in making the right decisions.

The research conducted by Soobaroyen and Poorundersing (2008) provided evidence that the four dimensions of MAS could mediate the effect of decentralization on managerial performance, while the one that was able to mediate the effect of task uncertainty on the managerial performance was only the aggregation dimension. Therefore, this present study has been conducted to provide empirical evidence about the effect of decentralization, task uncertainty and environment uncertainty mediated by the MAS dimensions.

The research by Supardiyono (1998) concluded that the MAS dimensions positively affect managerial performance when environment uncertainty is high, while when uncertainty is low 
the MAS dimensions have negative effects on managerial performance. This is consistent with the results of Gul's research (1991) which found that the MAS dimensions have positive and significant effects on environment uncertainty in improving managerial performance. Based on the above explanation, hypotheses can be formulated as follows:

$\mathrm{H}_{5 \mathrm{a}}$ : Decentralization positively affects managerial performance mediated by the broad scope dimension of MAS.

$\mathrm{H}_{5 \mathrm{~b}}$ : Decentralization positively affects managerial performance mediated by the timeliness dimension ofMAS.

$\mathrm{H}_{5 \mathrm{c}}$ : Decentralization positivelyaffects managerial performance mediated by the aggregation dimension ofMAS.

$\mathrm{H}_{5 \mathrm{~d}}$ : Decentralization positivelyaffects managerial performance mediated by the integration dimension ofMAS.

$\mathrm{H}_{6 \mathrm{a}}$ : Task uncertainty positively affects managerial performance mediated by the broad scope dimension of MAS.

$\mathrm{H}_{6 \mathrm{~b}}$ : $\quad$ Task uncertainty positively affects managerial performance mediated by thetimeliness dimension ofMAS.

$\mathrm{H}_{6 c}$ : Task uncertainty positively affects managerial performance mediated by the aggregation dimension ofMAS.

$\mathrm{H}_{6 \mathrm{~d}}$ : Task uncertainty positively affects managerial performance mediated by the integration dimension ofMAS.

$\mathrm{H}_{7 \mathrm{a}}$ : Environment uncertainty positively affects managerial performance mediated by the broad scope dimension of MAS.

$\mathrm{H}_{7 \mathrm{~b}}$ : Environment uncertainty positively affects managerial performance mediated by the timeliness dimension ofMAS.

$\mathrm{H}_{7 \mathrm{c}}$ : Environment uncertainty positively affects managerial performance mediated by the aggregation dimension ofMAS.

$\mathrm{H}_{7 \mathrm{~d}}$ : Environment uncertainty positively affects managerial performance mediated by the integration dimension ofMAS.

\section{Research Methodology}

\subsection{Population and Sample}

Similar to previous studies that involved manager population to test the variable dimensions of MAS, such as those conducted by Gordon and Narayanan (1884), Chenhall and Morris (1986), Gul (1991) and Soobaroyen and Poorundersing (2008), this study also took managers of companies located in Yogyakarta as the population. The targeted sample size of this study was 120 respondents because in this study there were eight variables and each variable required 15 respondents.

\subsection{Hypothesis Testing}

The analytical method used in this research is Partial Least Square (PLS), which follows the pattern of the equation model Structural Equation Modeling (SEM) based on the variance that can simultaneously test the measurement model and the structural model. The testing of the hypotheses of direct and mediation effects use a regression-path analysis. Path analysis is a statistical technique that aims to examine the effect of direct and indirect (mediation) contingency variables to managerial performance through the four dimensions of MAS (Wolfle,2003). 
Table 1. Results of Descriptive Statistics

\begin{tabular}{llcccc}
\hline \multicolumn{1}{c}{ Variable } & N & Minimum & Maximum & Average & $\begin{array}{c}\text { Standard } \\
\text { Deviation }\end{array}$ \\
\hline Decentralization & 125 & 10 & 25 & 19.12 & 2.864 \\
\hline Task Uncertainty & 125 & 6 & 20 & 15.08 & 2.484 \\
\hline Environment Uncertainty & 125 & 15 & 35 & 25.50 & 3.920 \\
\hline Broad scope & 125 & 12 & 29 & 22.83 & 2.856 \\
\hline Timeliness & 125 & 12 & 30 & 22.95 & 3.454 \\
\hline Aggregation & 125 & 18 & 30 & 22.77 & 2.413 \\
\hline Integration & 125 & 10 & 25 & 18.94 & 2.934 \\
\hline Managerial Performance & 125 & 20 & 40 & 32.25 & 4.211 \\
\hline Total & 125 & & & & \\
\hline Sourc: Exan
\end{tabular}

Source: Examined Primary Data

Table 2. Summary of the Results of Direct Effect Hypothesis Tests

\begin{tabular}{|c|c|c|c|c|c|c|}
\hline No. & Hypothesis & H & Beta & Significance & $\mathbf{R}^{2}$ & Status \\
\hline 1 & Decentralization positively affects the broad scope dimension of MAS & $\mathrm{H}_{1 \mathrm{a}}$ & 0.29 & $<0.01$ & 0.08 & Accepted \\
\hline 2 & Decentralization positively affects the timeliness dimension of MAS & $\mathrm{H}_{1 b}$ & 0.52 & $<0.01$ & 0.27 & Accepted \\
\hline 3 & Decentralization positively affects the aggregation $\mathrm{d}$ & $\mathrm{H}_{1 \mathrm{c}}$ & 0.40 & $<0.01$ & 0.16 & Accepted \\
\hline 4 & ets the inteoration dir & $\mathrm{H}_{1 \mathrm{~d}}$ & 0.43 & $<0.01$ & 0.18 & Accepted \\
\hline 5 & Task uncertainty positively affects the broad scope dimension of MAS & $\mathrm{H}_{2 \mathrm{a}}$ & $\begin{array}{l}-0.11 \\
\end{array}$ & $>0.10$ & 0.01 & Refuted \\
\hline 6 & Task & $\mathrm{H}_{2 \mathrm{~b}}$ & 0.45 & $\overline{<}$ & 0.20 & $\overline{\mathrm{ed}}$ \\
\hline 7 & Task uncertainty positively affects the broad scope dimension of MAS & $\mathrm{H}_{2 \mathrm{c}}$ & 0.13 & $<0.10$ & 0.02 & Accepted \\
\hline 8 & Task uncertainty positively affects the broad scope dimension of MAS & $\mathrm{H}_{2 \mathrm{~d}}$ & 0.37 & $<0.01$ & 0.14 & Accepted \\
\hline 9 & $\begin{array}{l}\text { Environment uncertainty positively affects the broad scope dimension of } \\
\text { MAS }\end{array}$ & $\mathrm{H}_{3 \mathrm{a}}$ & 0.17 & $<0.05$ & 0.03 & Accepted \\
\hline 10 & $\begin{array}{l}\text { Environment uncertainty positively affects the broad scope dimension of } \\
\text { MAS }\end{array}$ & $\mathrm{H}_{3 b}$ & 0.45 & $<0.01$ & 0.21 & Accepted \\
\hline 11 & $\begin{array}{l}\text { Environment uncertainty positively affects the broad scope dimension of } \\
\text { MAS }\end{array}$ & $\mathrm{H}_{3 \mathrm{c}}$ & 0.19 & $<0.05$ & 0.03 & Accepted \\
\hline 12 & $\begin{array}{l}\text { Environment uncertainty positively affects the broad scope dimension of } \\
\text { MAS }\end{array}$ & $\mathrm{H}_{3 \mathrm{~d}}$ & 0.47 & $<0.01$ & 0.22 & Accepted \\
\hline 13 & $\begin{array}{l}\text { The broad scope dimension of MAS positively affects managerial } \\
\text { performance. }\end{array}$ & $\mathrm{H}_{4 \mathrm{a}}$ & 0.23 & $<0.01$ & 0.05 & Accepted \\
\hline 14 & The timeliness dimension of MAS positively affects managerial performance. & $\mathrm{H}_{4 \mathrm{~b}}$ & 0.59 & $<0.01$ & 0.35 & Accepted \\
\hline 15 & $\begin{array}{l}\text { The aggregation dimension of MAS positively affects managerial } \\
\text { performance. }\end{array}$ & $\mathrm{H}_{4 \mathrm{c}}$ & 0.19 & $<0.05$ & 0.03 & Accepted \\
\hline 16 & $\begin{array}{l}\text { The integration dimension of MAS positively affects managerial } \\
\text { performance. }\end{array}$ & $\mathrm{H}_{4 \mathrm{~d}}$ & 0.61 & $<0.01$ & 0.37 & Accepted \\
\hline
\end{tabular}

Source: Examined Primary Data

\section{4. $\quad$ Results}

\subsection{Descriptive Statistics}

The descriptive statistics are based on the answers for as many as 125 items in the questionnaire. Table 1 presents the descriptive statistics on the variables of the present study. This table provides information about the minimum, maximum, average and standard deviations. 
Table 3. Summary of Mediation Effect Test Results

\begin{tabular}{|c|c|c|c|c|c|c|c|}
\hline No. & Comparison & $\mathbf{H}$ & Beta & Significance & Results & $\mathbf{R}^{2}$ & Status \\
\hline 1 & Decentralization effect on managerial performance & - & 0.52 & $<0.01$ & - & 0.27 & - \\
\hline 2 & Task uncertainty effect on managerial performance & - & 0.47 & $<0.01$ & - & 0.22 & - \\
\hline 3 & Environment uncertainty effect on managerial performance. & - & 0.58 & $<0.01$ & - & 0.33 & - \\
\hline No & Hypothesis & H & Beta & Significance & Result & $\overline{\mathbf{R}^{2}}$ & Status \\
\hline 1 & $\begin{array}{l}\text { Decentralization positively affects managerial performance } \\
\text { mediated by the broad scope dimension of MAS. }\end{array}$ & $\mathrm{H}_{5 \mathrm{a}}$ & 0.29 & $<0.01$ & Accepted & 0.30 & Partial \\
\hline 2 & $\begin{array}{l}\text { Decentralization positively affects managerial performance } \\
\text { mediated by the timeliness dimension of MAS. }\end{array}$ & $\mathrm{H}_{5 b}$ & 0.52 & $<0.01$ & Accepted & 0.41 & Partial \\
\hline 3 & $\begin{array}{l}\text { Decentralization positively affects managerial performance } \\
\text { mediated by the aggregation dimension of MAS. }\end{array}$ & $\mathrm{H}_{5 \mathrm{c}}$ & 0.40 & $<0.01$ & Accepted & 0.26 & Partial \\
\hline 4 & $\begin{array}{l}\text { Decentralization positively affects managerial performance } \\
\text { mediated by the integration dimension of MAS. }\end{array}$ & $\mathrm{H}_{5 \mathrm{~d}}$ & 0.43 & $<0.01$ & Accepted & 0.46 & Partial \\
\hline 5 & $\begin{array}{l}\text { Task uncertainty positively affects managerial performance } \\
\text { mediated by the timeliness dimension of MAS. }\end{array}$ & $\mathrm{H}_{6 \mathrm{a}}$ & -0.11 & $>0.10$ & Refused & 0.27 & - \\
\hline 6 & $\begin{array}{l}\text { Task uncertainty positively affects managerial performance } \\
\text { mediated by the timeliness dimension of MAS. }\end{array}$ & $\mathrm{H}_{6 \mathrm{~b}}$ & 0.45 & $<0.01$ & Accepted & 0.41 & Partial \\
\hline 7 & $\begin{array}{l}\text { Task uncertainty positively affects managerial performance } \\
\text { mediated by the aggregation dimension of MAS. }\end{array}$ & $\mathrm{H}_{6 \mathrm{c}}$ & 0.13 & $<0.1$ & Accepted & 0.23 & Partial \\
\hline 8 & $\begin{array}{l}\text { Task uncertainty positively affects managerial performance } \\
\text { mediated by the integration dimension of MAS. }\end{array}$ & $\mathrm{H}_{6 \mathrm{~d}}$ & 0.37 & $<0.01$ & Accepted & 0.44 & Partial \\
\hline 9 & $\begin{array}{l}\text { Environment uncertainty positively affects managerial } \\
\text { performance mediated bythe broad scope dimension of } \\
\text { MAS. }\end{array}$ & $\mathrm{H}_{7 \mathrm{a}}$ & 0.17 & $<0.05$ & Accepted & 0.34 & Partial \\
\hline 10 & $\begin{array}{l}\text { Environment uncertainty positively affects managerial } \\
\text { performance mediatedbythe timelinessdimensionof MAS. }\end{array}$ & $\mathrm{H}_{7 b}$ & 0.45 & $<0.01$ & Accepted & 0.47 & Partial \\
\hline 11 & $\begin{array}{l}\text { Environment uncertainty positively affects managerial } \\
\text { performance mediated by the aggregation dimension of } \\
\text { MAS }\end{array}$ & $\mathrm{H}_{7 \mathrm{c}}$ & 0.19 & $<0.05$ & Accepted & 0.34 & Partial \\
\hline 12 & $\begin{array}{l}\text { Environment uncertainty positively affects managerial } \\
\text { performance mediatedbythe integration dimensionof MAS. }\end{array}$ & $\mathrm{H}_{7 \mathrm{~d}}$ & 0.47 & $<0.01$ & Accepted & 0.48 & Partial \\
\hline
\end{tabular}

\subsection{Hypothesis Testing}

\subsection{The Effect of Decentralization on Management Accounting System Dimensions}

Table 2 above shows the beta coefficients of the effect of decentralization on the four dimensions of MAS, which includes broad scope, timeliness, aggregation and integration. The results of the testing of the first hypothesis (the effect of decentralization on the broad scope) showed a beta value of 0.29 and a significance level of $<0.01$. The results of the testing of the second hypothesis (the effect of decentralization on timeliness) showed a beta value of 0.527 and a significance level of $<0.01$.

For the third hypothesis (the effect of decentralization on aggregation), the testing resulted in the beta value of 0.40 and a significance level of $<0.01$, while for the fourth hypothesis (the effect of decentralization on integration) the results were a beta value of 0.43 and a significance level of $<0.01$. It can be concluded that decentralization has a positive affect the four dimensions of MAS that includes broad scope, timeliness, aggregation and integration. Therefore, H1a to H1d proposed in this study are accepted. 
Table 2 above shows the beta coefficients of the effect oftask uncertaintyon the four dimension of MAS, which consist of broad scope, timeliness, aggregation and integration. The testing of the first hypothesis (the effect of task uncertainty on the broad scope) showed a beta value of 0.11 and a significance level of $>0.1$. The testing of the second hypothesis (the effect of task uncertainty on timeliness) showed a beta value of 0.45 and a significance level of $<0.01$.

The testing of the third hypothesis (the effect of task uncertainty on aggregation) shows the beta value of 0.13 and a significance level of $<0.10$. The testing of the fourth hypothesis (the effect of task uncertainty on integration) showed a beta value of 0.37 and a significance level of $<0.01$. It can be concluded that task uncertainty positively affects three dimensions of MAS: timeliness, aggregation and integration. Therefore, $\mathrm{H}_{2 \mathrm{~b}}$ until $\mathrm{H}_{2 \mathrm{~d}}$ proposed in this study are accepted, while $\mathrm{H}_{2 \mathrm{a}}$ was rejected because the beta value is of a negative direction and is not significant.

\subsection{The Effect of Environment UncertaintyonManagement Accounting System Dimensions}

Table 2 above shows the beta coefficient of the effect of environment uncertainty on the four dimensions of MAS: broad scope, timeliness, aggregation and integration. The testing ofthe first hypothesis (the effect of environment uncertainty on the broad scope) shows a beta value of 0.17 and a significance level of $<0.05$. The testing of the second hypothesis (the effect of environment uncertainty on timeliness) shows a beta value of 0.45 and a significance level of $<0.01$.

The testing of the third hypothesis (the effect of environment uncertainty on aggregation) shows the beta value of 0.19 and a significance level of $<0.05$. The testing of the fourth hypothesis (the effect of environment uncertainty on integration) shows a beta value of 0.47 and a significance level of $<0.01$. It can be concluded that environment uncertainty positively affects the four dimensions of MAS. Therefore, $\mathrm{H}_{3 \mathrm{a}}$ until $\mathrm{H}_{3 \mathrm{~d}}$ proposed in this study areaccepted.

\subsection{The Effect of Management Accounting System on Managerial Performance}

Table 2 above shows the beta coefficient of the effect of broad scope, timeliness, aggregation and integration on managerial performance. The testing of the first hypothesis (the effect of broad scope dimension on managerial performance) shows the beta value of 0.23 and a significance level of $<0.01$. The testing of the second hypothesis (the effect of timeliness dimension on managerial performance) shows the beta value of 0.59 and a significance levelof $<0.01$.

The testing of the third hypothesis (the effect of aggregation dimension on managerial performance) shows the beta value of 0.19 and a significance level of $<0.05$. The testing of the fourth hypothesis (the effect of integration dimension on managerial performance) shows the beta value of 0.61 and a significance level of $<0.01$. It can be concluded that the four dimensions of MAS, which consist of broad scope, timeliness, aggregation and integration, have a positive effect on managerial performance. Therefore, $\mathrm{H}_{4 \mathrm{a}}$ until $\mathrm{H}_{4 \mathrm{~d}}$ proposed in this study are accepted. 
The Effect of Decentralization, Task Uncertainty and Environment Uncertainty on Managerial Performance with MAS Dimensions as MediationVariables

In this study, the effect of decentralization, task uncertainty and environment uncertainty on managerial performance was not directly tested because this study only tested the effect of the independent variables on the dependent variable mediated by MAS. To determine whether $\mathrm{H}_{5 \mathrm{a}}$ until $\mathrm{H}_{5 \mathrm{~d}}$ are accepted or rejected, the first step was testing the effect of independent variables on the dependent variable, and then the results were compared with the test results of the mediation.

If in the first test of the effect of the independent variables on the dependent variable obtains significant results while in the second test the effect of the independent variables on the dependent variable does not yield significant values, then it is called perfect mediation. If in the first test of the effect of independent variables on the dependent variable obtains significant results and in the second test of the effect ofthe independent variable on the dependent variables also obtains significant results, then it is called partial mediation.

Table 3 above presents the beta coefficients of the effect of decentralization on managerial performance mediated by the four dimensions of MAS. The testing of the effect of decentralization on managerial performance shows a beta coefficient of 0.52 and a significance level of $<0.01$. The testing of the effect of decentralization on managerial performance mediated by the four dimensions MAS for the first hypothesis (the effect of decentralization on managerial performance that is mediated by the broad scope dimension) shows a beta coefficient of 0.29 and a level of significance $<0.01$. The testing for the second hypothesis (the effect of decentralization on managerial performance that is mediated by the timeliness dimension) shows a beta coefficient of 0.52 and a significance level of $<0.01$.

The testing for the third hypothesis (the effect of decentralization on managerial performance that is mediated by aggregation dimension) shows a beta coefficient of 0.40 and a significance level of $<0.01$. The testing for the fourth hypothesis (the effect of decentralization on managerial performance that is mediated by integration dimension) shows a beta coefficient of 0.43 and a significance levelof $<0.01$. Based on the test results of the four hypotheses, it can be concluded that decentralization positively affects the managerial performance mediated by the four dimensions of MAS. Therefore, hypotheses $\mathrm{H}_{5 \mathrm{a}}$ until $\mathrm{H}_{5 \mathrm{~d}}$ proposed in this study areaccepted.

Table 3 above presents the beta coefficients of the effect of task uncertainty on managerial performance mediated by the four dimensions of MAS (broad scope, timeliness, aggregation and integration). The test results of task uncertainty on managerial performance shows a beta coefficient of 0.47 and a significance level of $<0.01$. The testing for the first hypothesis (the effect of task uncertainty on managerial performance that is mediated by the broad scope dimension) shows a beta coefficient of -0.11 and a significance level of $>0.10$. The testing of the second hypothesis (the effect of task uncertainty on managerial performance that is mediated by the timeliness dimension) shows a beta coefficient of 0.45 and a significance level of $<0.01$.

The testing for the third hypothesis (the effect of task uncertainty on managerial performance that is mediated by aggregation dimension) shows a beta coefficient of 0.13 and a significance level of $<0.10$. The testing for the fourth hypothesis (the effect of task uncertainty on the managerial performance that is mediated by integration dimension) shows a beta coefficient of 0.37 and a significance level of $<0.01$. Based on the results of the testing of the four hypotheses, 
it can be concluded that task uncertainty positively affects managerial performance mediated by three MAS dimensions, namely timeliness, aggregation and integration. The test results accept $\mathrm{H}_{6 \mathrm{~b}}$ until $\mathrm{H}_{6 \mathrm{~d}}$ proposed in this study. The results of the testing for $\mathrm{H}_{6 \mathrm{a}}$ show that the task uncertainty negatively affects managerial performance mediated by the broad scope dimension, so $\mathrm{H}_{6 \mathrm{a}}$ in this study is rejected.

Table 3 above presents the beta coefficients of the effect of environment uncertainty on managerial performance mediated by the four MAS dimensions (broad scope, timeliness, aggregation and integration). The testing of the effect of environment uncertainty on the managerial performance shows a beta coefficient of 0.58 and a significance level of $<0.01$. The testing for the first hypothesis (the effect of environment uncertainty on managerial performance that is mediated bythe broad scope dimension) shows a beta coefficient of 0.17 and a significance level of $<0.05$. The testing for the second hypothesis (the effect of environment uncertainty on managerial performance mediated by the timeliness dimension) shows a beta coefficient of 0.45 and a significance level of $<0.01$.

The testing of the third hypothesis (the effect of task uncertainty on the managerial performance mediated by aggregation dimension) shows a beta coefficient of 0.19 and a significance level of $<0.05$. The testing for the fourth hypothesis (the effect of environment uncertainty on managerial performance mediated by integration dimension) shows a beta coefficient of 0.47 and a significance level of $<0.01$. Based on the test results of the four hypotheses, it can be concluded that environment uncertainty positively affects managerial performance mediated by the four MAS dimensions. These test results accept $\mathrm{H}_{7 \mathrm{a}}$ until $\mathrm{H}_{7 \mathrm{~d}}$ proposed in this present study.

\section{Summary}

\subsection{Conclusion}

The results of the testing for hypotheses $1 \mathrm{a}$ to $1 \mathrm{~d}$ are the same as those of the research conducted by Soobaroyen and Poorundersing (2008) for the effect of decentralization on the four MAS dimensions, which consist of broad scope, timeliness, aggregation and integration. The results of the testing for Hypotheses $2 \mathrm{a}$ tol $2 \mathrm{~d}$ in this present study are different from those of the research conducted by Soobaroyen and Poorundersing (2008).

In this present research task uncertainty positively affects the three MAS dimensions, namely timeliness, aggregation and integration, while task uncertainty does not affect the MAS dimension of broad scope. Task uncertainty is not relevant to broad scope because this dimension of MAS cannot produce information related to the tasks in the company. Thebroad scope dimension generates internal and external information, which is is focused, quantitative and timely but not related to managers' task uncertainty. Therefore, managers in carrying out their duties require information only from internal parties to help them resolve the problem of task uncertainty.

The results of the testing for Hypotheses $3 \mathrm{a}$ to $3 \mathrm{~d}$ are the same as those of the results of the researches conducted by Gul(1991), Gul and Chia (1994) and Mia and Chenhall (1994), which stated that environment uncertainty positively affects the four dimensions of MAS. The results of the testing for Hypotheses $4 \mathrm{a}$ to $4 \mathrm{~d}$ in this study are the same as the results of Poorundersing and Soobaroyen's research (2008) which showed that the four MAS dimensions of MAS (broad 
scope, timeliness, aggregation and integration) positively effects managerial performance. The results of the testing for Hypotheses $5 \mathrm{a}$ to $5 \mathrm{~d}$ are the same as those of the research conducted by Soobaroyen and Poorundersing (2008) which showed that the four MAS dimensions (broad scope, timeliness, aggregation and integration) can mediate the effect of decentralization on managerial performance.

The results of the testing for Hypotheses $6 \mathrm{a}$ to $6 \mathrm{~d}$ differ from those of the results of research conducted by Soobaroyen and Poorundersing (2008) which provide evidence that three MAS dimensions (broad scope, timeliness and integration) fail to mediate the effect oftask uncertainty on managerial performance, while the aggregation dimension can mediate the negative effect of task uncertainty on managerial performance. Conversely, in this study, three MAS dimensions (timeliness, aggregation and integration) can mediate the effects of task uncertainty on the managerial performance partially, while broad scope dimension cannot. Broad scope cannot mediate the effect of task uncertainty on managerial performance as company managers do not need a broad range of information to help them resolve the problem of task uncertainty. Information broad scope is not relevant to task uncertainty because managers have a higher need of information generated by the dimensions of timeliness, aggregation and integration to overcome the problems of task uncertainty.

The results of the testing for Hypotheses 7a to 7d are consistent with the results of Supardiyono's research (1999), which found that all of the MAS dimensions positively affect managerial performance under the condition ofenvironment uncertainty. The results are also consistent with those of Gul's research (1991), which reported positive and significant effects of environment uncertainty in improving managerial performance. In this study, all MAS dimensions can partially mediate the effect of environment uncertainty on managerial performance. The results of this present research are consistent with those of the research of Agbejule (2005), who found positive effects of environment uncertainty on manager performance mediated by MAS dimension.

\subsection{Limitations}

In this study, there are three limitations. Firstly, the company size and managers' education level in this study are not proportionally represented in the sample, which might lead to bias in the results. Secondly, the use of self-rating scale in the measurement of managerial performance in this study made the scores of managers' performance higher than what it supposed to be. This limitation has also been recognized by other researchers such as Gul (1991), Chong (1996), Nazaruddin (1998) and Soobaroyen and Poorundersing (2008). Thirdly, the time available for distributing and collecting the questionnaire is relatively short.

\subsection{Suggestions}

Based on the above limitations, the following suggestions are presented for the improvement of future research. First, in future studies the company size and the managers' education level must be proportionally represented in the sample. Second, a more objective tool of measurement for managerial performance must be developed to prevent bias results. Third, in future studies, contextual variables that can affect MAS dimensions and managerial performance such as organizational culture, leadership, business strategy must be added. Fourth, in future studies the time for data collection should be extended to cover more respondents. 


\section{References}

Agbejule, Adebayo. (2005). The Relationship Between Management Accounting Systems and Perceived Environmental Uncertainty on Managerial Performance: A Research Note. Accounting and Business Research, 35 (4), 295-350.

Bouwens, Jan and Margaret A. Abernethy. (2000). The Consequences of Customization on Management Accounting System Design. Accounting Organization and Society. pp. 221-241.

Chenhall, Robert H. and Deigan Morris. (1986). The Impact of Structure, Environment, and Interdependence on the Perceived Usefulness of Management Accounting Systems. The Accounting Review. No. 1. pp. $16-35$.

Chia, Yew Ming. (1995). Decentralization, Management Accounting System (MAS) Information Characteristics and Their Interaction Effect on Managerial Performance: A Singapore Study. Journal of Business Finance and Accounting. September. pp. 811-830.

Chong, Vincent K. and Kar Ming Chong. (1997). Strategic Choices, Environmental Uncertainty and SBU Performance: A Note on the Intervening Role of Management Accounting System. Accounting and Business research. Vol. 27. No. 4. pp 268-276.

Chong, Vincent K. and R. C. Eggleton. (2003). The Decision-Facilitating Role of Management Accounting Systems on Managerial performance: The Influence of Locus of Control and Task Uncertainty. Advances in Accounting. Vol. 20. pp. 165-197.

Dwirandra, Anak Agung Ngurah Bagus. (2007). Pengaruh Interaksi Ketidakpastian Lingkungan, Desentralisasi, dan Luas Lingkup Informasi Akuntansi Manajemen terhadap Kinerja Manajerial. Buletin Studi Ekonomi, 12 (2). 232-244.

Gordon, L. A. and Danny A. Miller. (1976), A Contingency Framework for the Design of Accounting Information Systems. Accounting Organizations and Society. pp. 56-59.

Gordon, L. A. and V. K. Narayanan. (1984). Management Accounting Systems, Perceived Environmental Uncertainty and Organizational Structure: An Empirical Investigation. Accounting, Organization and Society. 9: 33-47.

Gul, Ferdinand. (1991). The Effect of Management Accounting Systems and Environmental Uncertainty on Small Business Managers' Performance. Accounting and Business Research 22(85): 57-61.

Gul, Ferdinand and Yew Ming Chia. (1994). The Effect of Management Accounting System, Perceived Environmental Uncertainty and Decentralization on Managerial Performance: A Test of Three-Way Interaction. Accounting, Organization and Society. Vol. 19. No. 45. pp. 413-426.

Hinings, C. R., D. J. Hickson, J. M. Pennings and R. E. Schneck. (1974). Structural Conditions of Intraorganizational Power. Administrative Science Quarterly. Vol. 19. No. 1. (Mar., 1974) pp. 22-44. 
Hirst, Mark K. (1981). Accounting Information and the Evaluation of Subordinate Performance: AStituational Approach. The Accounting Review. Vol. LVI No. 4 October. PP. 771-784.

Islam, Jesmin, and Hui Hu. (2012). A Review of Literature on Contingency Theory in Managerian Accounting. African Journal of Business Management. Vol.16 (15). pp. 5159-5164. 18 April, 2012.

Kaplan, Robert. S. (1984). The Evolution of Management Accounting. The Accounting Review. July. Pp.390-418.

Mahoney, T. A., T. H. Jerdee, and S. J. Caroll. (1963). Development of Managerial Performance: A Research Approach. South-Western Publishing. Cincinnati. OH.

Mia, L. and R.H. Chenhall (1994). The Usefulness of Management Accounting Systems, Functional Differentiation and Managerial Effectiveness. Accounting, Organization, and Society. 19. 1 - 13.

Nazaruddin, Itje. (1998). Pengaruh Desentralisasi dan Karateristik Informasi Sistem Akuntansi Manajemen terhadap Kinerja Manajerial. Jurnal Riset Akuntansi Indonesia, Vol.1 (2), Hal 141-162.

Otley, David. T. (1980). The Contingency Theory of Management Accounting: Achievement and Prognosis. Accounting Organizations and Society. Vol.5. pp. 413-428.

Soobaroyen, T. and B. Poorundersing. (2008). The Effectiveness of Management Accounting Systems. Managerial Auditing Journal. Vol. 23 No.2. pp. 187-219.

Supardiyono, Y. P. (1999). Pengaruh Ketidakpastian Lingkungan dan Struktur Organisasional terhadap Efektivitas Sistem Akuntansi Manajemen dalam Meningkatkan Kinerja Manajerial. Master Thesis. Yogyakarta: ETD UGM.

Sutapa. (2003). Pengaruh Sistem Akuntansi Manajemen. Ketidakpastian Lingkungan (Perceived Environmental Uncertainty) dan Desentralisasi Terhadap Kinerja Manajerial. Master Thesis. Semarang: Universitas Diponegoro.

Tsui, J. S. L. (2001). The Impact of Culture on the Relationship between Budgetary Participation, Management Accounting Systems and Managerial Performance: An Analysis of Chinese And WesternManagers. The International Journal of Accounting. Vol.36. No. 2. pp. 125-46.

Waterhouse, J. H. and P.Tiesen. (1978). AContingency Framework for Management Accounting System Research. Accounting, Organization and Society. Vol3. No. 1.pp. 65-76.

Whitney, M., R. L. Daft dan W.H. Cooper, (1983). Measures ofPerrrow's Work Unit Technology: An Empirical Assessment and a New Scale. Academy of Management Journal. Vol. 26. No. 1. pp. 45-63. 
Wolfle, L.M. (2003). The Introduction of Path Analysis to the Social Sciences, and Some Emergent Themes: An Annotated Bibliography. Structural Equation Modeling: A Multidisciplinary Journal, Vol. 10. No. 1, pp. 1-34.

\section{A book}

Anthony, R. N., J. Dearden and N. M. Bedford. (1998). Management Control Systems, Homewood. $6^{\text {th }}$ edition. Irwin: Homewood.

Atkinson, A. A., R. J. Banker, R. S. Kaplan and S. M. Young. (1995). Management Accounting. Englewood Cliffs. NJ: Prentice Hall.

Robbins, Stephen P. (1994). Organization Theory. Englewoods Cliffs: Prentice Hall.

Supomo, Bambang dan Nur Indriantoro. (1998). Metodologi Penelitian Untuk Bisnis Akuntansi dan Managemen. Yogyakarta: BPFE. 